\title{
The flaky Cd film on Cu plate substrate: An active and efficient electrode for electrochemical reduction of $\mathrm{CO}_{2}$ to formate
}

\author{
Zhipeng Chen ${ }^{\mathrm{a}, \mathrm{b}}$, Nailiang Wang ${ }^{\mathrm{a}}$, Shuyu Yao ${ }^{\mathrm{a}}$, Licheng Liu ${ }^{\mathrm{a}, *}$ \\ ${ }^{\text {a } C A S ~ K e y ~ L a b o r a t o r y ~ o f ~ B i o-b a s e d ~ M a t e r i a l s, ~ Q i n g d a o ~ I n s t i t u t e ~ o f ~ B i o e n e r g y ~ a n d ~ B i o p r o c e s s ~ T e c h n o l o g y, ~ C h i n e s e ~ A c a d e m y ~ o f ~ S c i e n c e s, ~ Q i n g d a o ~ 266101, ~ S h a n d o n g, ~}$ \\ China \\ b University of Chinese Academy of Sciences, Beijing 100049, China
}

\section{A R T I C L E I N F O}

\section{Keywords:}

Electrocatalytic

$\mathrm{CO}_{2}$ reduction

Vacuum evaporation coating

Formate

\begin{abstract}
A B S T R A C T
Efficient electrochemical reduction of $\mathrm{CO}_{2}$ to formate was studied on a $\mathrm{Cu} / \mathrm{Cd}$ composite electrode in $0.5 \mathrm{M}$ $\mathrm{KHCO}_{3}$ aqueous solution, which was prepared by vacuum evaporation coating $\mathrm{Cd}$ film on the Cu plate substrate. The results showed that a novel flaky $\mathrm{Cd}$ film was deposited on the $\mathrm{Cu}$ plate substrate successfully. The performance of formate production on the $\mathrm{Cu} / \mathrm{Cd}$ composite electrode was related to the electrolysis potential and the thickness of $\mathrm{Cd}$ film. The electrocatalytic activity of $\mathrm{Cu} / \mathrm{Cd}$ composite electrode toward $\mathrm{CO}_{2}$ reduction was enhanced in comparison with pure $\mathrm{Cu}$ plate and Graphite-Paper/Cd (G-P/Cd) electrodes. The maximum Faradaic efficiency of $76.2 \%$ for formate production has been obtained with high stability and current densities of $10.6 \mathrm{~mA} \mathrm{~cm}^{-2}$ at $-1.8 \mathrm{~V}$ (vs. $\mathrm{Ag} / \mathrm{AgCl}$ ) on the composite electrode with depositing a $\sim 300 \mathrm{~nm}$ thick Cd film on the $\mathrm{Cu}$ substrate.
\end{abstract}

\section{Introduction}

In recent years, the electrochemical reduction of $\mathrm{CO}_{2}$ for producing value-added chemicals in aqueous solutions has attracted much attention because it is energy-efficient compared with other methods [1-6]. Among many products from $\mathrm{CO}_{2}$ reduction, formate is one of the relatively high economic value products [7]. It is well known that formate is a basic organic chemical raw materials, which was widely used in pesticides, leather, dyes, pharmaceutical and rubber industries [8]. It can also be directly as fuel for the fuel cells to generate electricity [9-11]. Thus, it is very attractive to convert $\mathrm{CO}_{2}$ into value-added formate by electrochemical reduction.

So far, many kinds of catalysts have been used in the electrochemical reduction of $\mathrm{CO}_{2}$, such as pure metals, metallic oxide, metalorganic compounds and alloys [12-17]. As a conventional electrode, metal and its alloy electrodes have been widely investigated due to its excellent performance on $\mathrm{CO}_{2}$ reduction. For example, previous work has shown that on the $\mathrm{Cd}, \mathrm{Pb}, \mathrm{Sn}, \mathrm{Hg}$ and $\mathrm{In}$ electrodes, $\mathrm{CO}_{2}$ can be reduced to formate with high efficiency in aqueous solutions [18-22]. On the $\mathrm{Zn}, \mathrm{Ag}$ and $\mathrm{Au}$ electrode, the main product of $\mathrm{CO}_{2}$ reduction was $\mathrm{CO}$ [23-27]. Comparatively, $\mathrm{Cu}$ is a special electrode for $\mathrm{CO}_{2}$ reduction because the product is widely distributed, including both hydrocarbons and formate, CO, methanol and ethanol [28-32]. Therefore, among the various metallic electrodes, Cu-based composite materials are the most widely studied electrodes [33-35].

Although the $\mathrm{Cu}$ electrode exhibited excellent electrocatalytic activity of $\mathrm{CO}_{2}$ reduction, poor stability was always observed during the process of electrolysis. It was usually deactivated at $20-30 \mathrm{~min}$ after the beginning of the electrolysis [36]. Moreover, the Faradaic efficiency of formate production is not high enough. For example, Qiao et al. prepared a fibrous copper electrode and achieved the highest Faradaic efficiency of $43 \%$ for producing formate [37]. Sen et al. explored the performance of $\mathrm{CO}_{2}$ reduction on a porous $\mathrm{Cu}$ foams electrode and achieved Faradaic efficiency of $37 \%$ for producing formate [28]. In order to improve the performance of $\mathrm{CO}_{2}$ reduction on $\mathrm{Cu}$ electrode, we consider depositing another metal which is efficiently for formate production on the $\mathrm{Cu}$ substrate electrode to prepare a $\mathrm{Cu}$-based composite electrode. It has been known that the Cd has a high $\mathrm{H}_{2}$ evolution potential and easy to produce formate efficiently in the process of $\mathrm{CO}_{2}$ reduction [25]. In addition, the Cd electrode is well conductive and cost effective. Thus, $\mathrm{Cd}$ was selected as a nano-coating deposited on the $\mathrm{Cu}$ plate electrode to form a composite electrode, which can provide excellent electrocatalytic performance for $\mathrm{CO}_{2}$ reduction to formate.

Furthermore, the performance of $\mathrm{CO}_{2}$ reduction has a strong dependence on the preparation method of the composite electrode. Tang et al. has reported the differences in selectivity toward $\mathrm{CO}_{2}$ reduction on $\mathrm{Cu}$ electrodes with three different morphologies, which were prepared by the electropolish, sputter coat, and nanoparticle coat methods,

\footnotetext{
* Corresponding author

E-mail address: liulc@qibebt.ac.cn (L. Liu).
} 

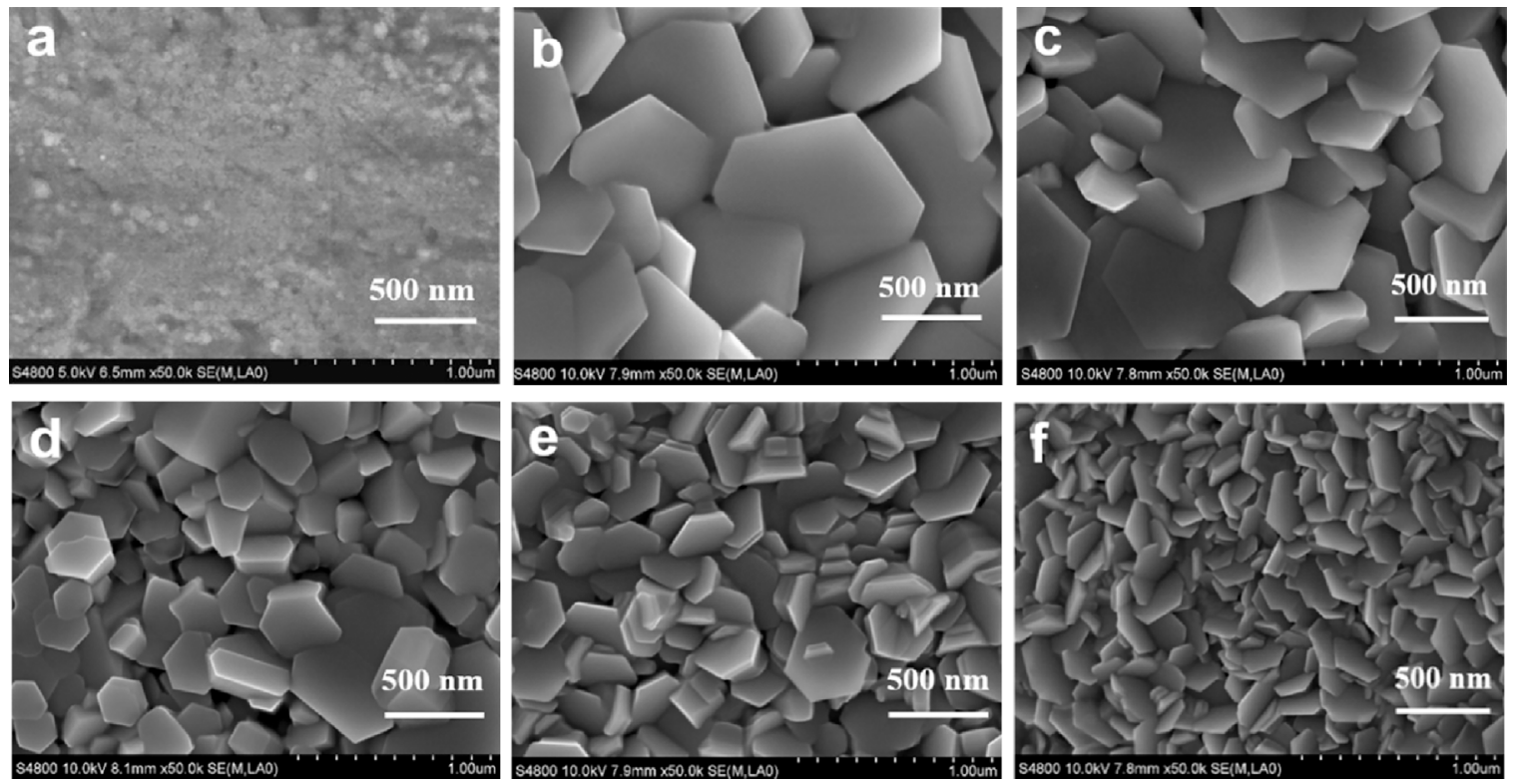

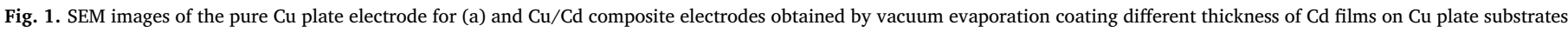
for (b) $100 \mathrm{~nm}$. (c) $200 \mathrm{~nm}$. (d) $300 \mathrm{~nm}$. (e) $400 \mathrm{~nm}$. (f) $500 \mathrm{~nm}$.

respectively. They found that the last two methods tended to generate hydrocarbons compared with the electropolish [38]. Especially, the Faradaic efficiency of formate production the Cu-based composite electrodes prepared by electrodeposition and electroplating methods is not efficient enough. For example, Hori et al. in-situ electrodeposited $\mathrm{Cd}$ on $\mathrm{Cu}$ electrodes and found that a small amount of $\mathrm{Cd}$ heavily promoted the reduction of $\mathrm{CO}_{2}$ to $\mathrm{CO}$, but the Faradaic efficiency for producing formate had no obvious change compared with the $\mathrm{Cu}$ electrode [39]. Watanabe et al. prepared Cu-Cd alloy by electroplating from conventional plating baths and obtained the highest Faradaic efficiency only of $43 \%$ [25].

In this work, a novel flaky $\mathrm{Cd}$ film was deposited on the $\mathrm{Cu}$ plate substrate through the vacuum evaporation deposition method. This method allows a large-scale preparation of homogeneous composite electrode in industry. In order to achieve the optimal experimental conditions, the effect of thickness of Cd film and applied potential on the electrocatalytic activity toward $\mathrm{CO}_{2}$ reduction have been investigated.

\section{Experimental}

\subsection{Preparation of composite electrodes}

A substrate electrode was fabricated out of a $\mathrm{Cu}$ plate $(1 \times 1 \mathrm{~cm}$, $0.1 \mathrm{~cm}$ ), which was polished by 400 grade sandpaper firstly and then was ultrasonic cleaned by acetone, $0.5 \mathrm{M}$ hydrochloric acid, deionized water, respectively. The $\mathrm{Cd}$ metal particles as a $\mathrm{Cd}$ source for vacuum evaporation coating Cd films were purchased ( $\geq 99.99 \%)$ from Shanghai Macklin Biochemical Co., Ltd, and without any further pretreatment before used. The $\mathrm{Cu} / \mathrm{Cd}$ composite electrode was prepared by vacuum evaporation coating $\mathrm{Cd}$ film on the $\mathrm{Cu}$ plate substrate by the ZHD300 high vacuum resistance evaporative coating machine (Beijing Ticonuo Technology Co., Ltd, China) in this experiment. The rate for depositing Cd film was $10 \AA^{-1}$ and the thicknesses of Cd film deposited on Cu plate substrate were controlled to 100, 200, 300, 400 and $500 \mathrm{~nm}$, respectively. In addition, the Graphite-Paper/Cd (G-P/Cd) composite electrode was obtained by vacuum evaporation coating a $300 \mathrm{~nm}$ thick Cd film on the inert graphite paper electrode, which was used in the comparative experiment.

\subsection{Electrochemical experiments}

A three electrode test was carried out in a sealed H-cell which was separated by Nafion N117 membrane. A Cu/Cd composite electrode was used as the working electrode. The counter and reference electrodes are $\mathrm{Ag} / \mathrm{AgCl}$ and Pt plate $(1 \times 1 \mathrm{~cm})$, respectively. A CHI630C electrochemical analyzer (Shanghai chenhua instrument co. LTD, China) was used in all the electrochemical experiments. Cyclic voltammetry (CV) and Constant potential electrolysis (i-t) experiments were studied in $0.5 \mathrm{~mol} \mathrm{~L}^{-1} \mathrm{KHCO}_{3}$. Before the start of experiments, constant bubbling $\mathrm{N}_{2}(99.99 \%)$ and $\mathrm{CO}_{2}(99.99 \%)$ for 30 min to remove $\mathrm{O}_{2}$ from the $\mathrm{H}$-cell and electrolyte. The flow rate of $\mathrm{CO}_{2}$ was $40 \mathrm{~mL} \mathrm{~min}^{-1}$ in the process of $\mathrm{CO}_{2}$ reduction. Current density $\left(j_{\mathrm{a}}\right)$ was determined on the geometrical area of the working electrode $\left(1 \mathrm{~cm}^{2}\right)$. All the experiments were studied at atmospheric pressure and room temperature $\left(25 \pm 3{ }^{\circ} \mathrm{C}\right)$.

\subsection{Characterization and analysis}

The scanning electron microscope (SEM) pictures were obtained through the Hitachi S-4800 high-resolution electron microscope without any conductive coating.

The atomic force microscope (AFM) images were provided by the Agilent Technologies 5500 scanning probe microscope in the tapping mode. The images with an area of $2.5 \mu \mathrm{m} \times 2.5 \mu \mathrm{m}$ were investigated.

$\mathrm{X}$-ray diffraction (XRD) patterns were obained on the $\mathrm{D} 8$ advance $\mathrm{X}$ ray Diffractometer from Bruker with $\mathrm{Cu} \mathrm{K} \alpha$ radiation $(\lambda=1.541 \AA$ ). The XRD were recorded in the range of 10 to $80^{\circ}$, with degree steps of 0.02 and acquisition times of $0.1 \mathrm{~s} \mathrm{step}^{-1}$.

Liquid phase products were quantified by a high performance liquid chromatography (HPLC, Agilent 1200) with the Aminex HPX-87H Ion Exclusion columns. The mobile phase was $5 \mathrm{~m} \mathrm{M} \mathrm{H}_{2} \mathrm{SO}_{4}$, and injection rate was $0.5 \mathrm{~mL} \mathrm{~min}^{-1}$. The amount of measurement was $10 \mu \mathrm{L}$ every time.

Faradaic efficiency $(\eta)$ of fomate production was achieved by the formula:

$\eta=2 n F / Q$

where $\eta$ is Faradaic efficiency of formate; 2 represents the number of electrons required to form formate from $\mathrm{CO}_{2} ; n$ represents the total number of moles of fomate production, which was measured by HPLC; 
$F$ represents Faraday constant (96485); and the $Q$ corresponds to the amount of cumulative charge in the process of $\mathrm{CO}_{2}$ reduction, which was provided by the electrochemical workstation.

\section{Results and discussion}

Shown in Fig. 1 are surface images of the pure $\mathrm{Cu}$ plate and $\mathrm{Cu} / \mathrm{Cd}$ electrodes obtained by vacuum evaporation depositing different thickness of $\mathrm{Cd}$ films on $\mathrm{Cu}$ plate substrates. The image (a) shows that the surface morphology of the pure $\mathrm{Cu}$ electrode is still a bit rough after being polished by 400 grade sandpaper. The images (b), (c), (d), (e) and (f) correspond to $100 \mathrm{~nm}, 200 \mathrm{~nm}, 300 \mathrm{~nm}, 400 \mathrm{~nm}$ and $500 \mathrm{~nm}$ thickness of Cd film, respectively. It can be seen that the morphology of $\mathrm{Cd}$ particles were vacuum evaporation deposited on the $\mathrm{Cu}$ plate substrate are mostly irregular flakes and have been coated on the $\mathrm{Cu}$ plate substrate successfully. From Fig. 1(b)-(f), as the controlled thickness of coating film increases further, the $\mathrm{Cd}$ flakes deposited on $\mathrm{Cu}$ plate substrate become smaller, resulting in denser accumulation of $\mathrm{Cd}$ flakes. This could be caused by the reason that the internal stress of the film increases when the thickness of film increases further.

AFM images of $\mathrm{Cu} / \mathrm{Cd}$ composite electrode with $300 \mathrm{~nm}$ thick $\mathrm{Cd}$ film is shown in Fig. 2 to explore the surface roughness of the electrode. The images reveal that the

Cd flakes are with multiple shapes and piled up randomly. The deposited Cd film has highly rough and porous surface morphology. The analysis of the AFM imageshows that the average surface roughness of the film is $58.7 \mathrm{~nm}$. The porous structure and rough surface of the $\mathrm{Cd}$ film are useful to increase electrocatalytic activity sites of $\mathrm{CO}_{2}$ reduction and the electrocatalytic performance of composite electrode on $\mathrm{CO}_{2}$ reduction could be enhanced in this way.

Shown in Fig. 3 is the X-ray diffractogram (XRD) of the pure $\mathrm{Cu}$ electrode, the $\mathrm{Cu} / \mathrm{Cd}$ and G-P/Cd composite electrodes, which were deposited $300 \mathrm{~nm}$ thick $\mathrm{Cd}$ films on the $\mathrm{Cu}$ plate and graphite paper substrate, respectively. The result indicate that the $\mathrm{Cu} / \mathrm{Cd}$ composite electrode exhibits high crystallinity and the peaks at $43.3^{\circ}, 50.4^{\circ}$ and $74.1^{\circ}$ correspond to (111), (200) and (220) crystal facets of $\mathrm{Cu}$ plate (PDF\# 04-0836), respectively. These at $31.8^{\circ}, 34.7^{\circ}, 38.4^{\circ}$ and $66.6^{\circ}$ are assigned to (002), (100), (101) and (004) crystal facets of the deposited Cd film (PDF\# 05-0674), respectively. Obviously, the crystal structures of $\mathrm{Cu}$ and $\mathrm{Cd}$ were not destroyed and there was no alloying in the process of preparing composite electrode. Furthermore, the ratio of the diffraction intensity of (002) and (101) crystal facets is 10.2 for the $\mathrm{Cu} / \mathrm{Cd}$ composite electrode. For comparison, this ratio is 7.7 for the G$\mathrm{P} / \mathrm{Cd}$ composite electrode. Although identical crystal facets are observed in both electrodes, the intensity of (002) facet on the $\mathrm{Cu} / \mathrm{Cd}$ is $\sim 33 \%$ higher than that on the G-P/Cd composite electrode. This difference suggests the preferential growth low index crystal face on $\mathrm{Cu}$ /

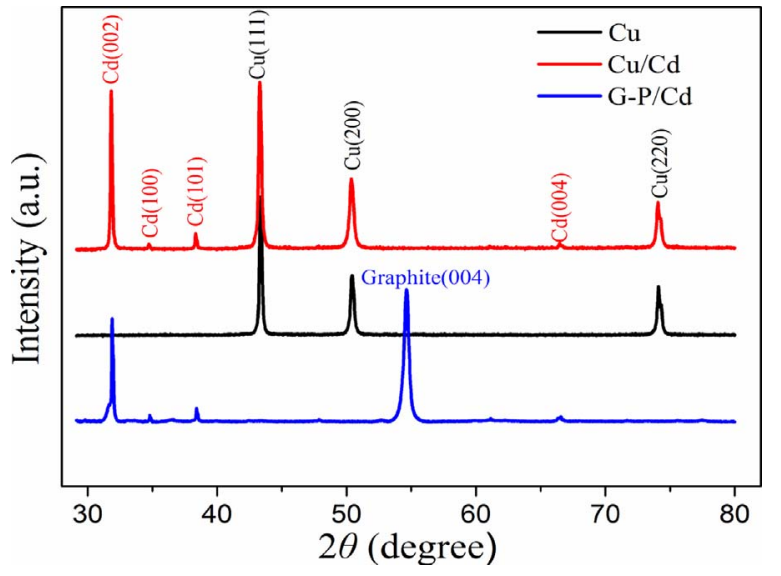

Fig. 3. XRD patterns of the pure $\mathrm{Cu}$ electrode, $\mathrm{Cu} / \mathrm{Cd}$ and $\mathrm{G}-\mathrm{P} / \mathrm{Cd}$ composite electrodes.

Cd and may be beneficial to the efficiency of formate production in the electrochemical reduction of $\mathrm{CO}_{2}[40,41]$.

Fig. 4a shows the cyclic voltammogram of $\mathrm{Cu} / \mathrm{Cd}$ composite electrode which is deposited $300 \mathrm{~nm}$ thick Cd film on the Cu plate substrate in $0.5 \mathrm{M} \mathrm{KHCO}_{3}$ electrolyte solution. As shown in the inset, the onset reduction potential under $\mathrm{N}_{2}(-1.1 \mathrm{~V})$ is more negative than that under $\mathrm{CO}_{2}(-0.95 \mathrm{~V})$. The result reveals that the $\mathrm{Cu} / \mathrm{Cd}$ composite electrode exhibits excellent electrocatalytic activities toward electrochemical reduction of $\mathrm{CO}_{2}$. It is also observed that the current density increases sharply in both $\mathrm{N}_{2}$ and $\mathrm{CO}_{2}$ at more negative potentials and the current density under $\mathrm{N}_{2}$ is lower than that under $\mathrm{CO}_{2}$. The $\mathrm{Cu} / \mathrm{Cd}$ composite electrode exhibits excellent electrocatalytic activities toward $\mathrm{CO}_{2}$ reduction. The sharp increase of the current density under $\mathrm{N}_{2}$ should be attributed to the electrolysis of water $\left(\mathrm{H}_{2}\right.$ evolution reaction) and the current density under $\mathrm{CO}_{2}$ is attributed to both the electrolysis of water and reduction of $\mathrm{CO}_{2}$ [42]. Fig. 4b shows the cyclic voltammograms of $\mathrm{Cu} / \mathrm{Cd}$ and G-P/Cd composite electrodes in $0.5 \mathrm{M} \mathrm{KHCO}_{3}$ electrolyte solution purged with $\mathrm{CO}_{2}$ and the sweep rate is $50 \mathrm{mV} \mathrm{s}^{-1}$. Obviously, the $\mathrm{Cu} / \mathrm{Cd}$ composite electrode possess higher activity than the G-P/Cd electrode, as manifest a higher current density of $\mathrm{CO}_{2}$ reduction. The current density of the $\mathrm{Cu} / \mathrm{Cd}$ composite electrode is almost twice that of the G-P/Cd electrode. Shown in Fig. $4 \mathrm{c}$ are the $\mathrm{CVs}$ of $\mathrm{Cu} / \mathrm{Cd}$ composite electrode obtained at different sweep rates and the inset of Fig. $4 \mathrm{c}$ are the $\mathrm{CVs}$ of the $\mathrm{Cu}, \mathrm{G}-\mathrm{P} / \mathrm{Cd}$ and $\mathrm{Cu} / \mathrm{Cd}$ electrodes at $50 \mathrm{mVs}^{-1}$, respectively. It can be seen that, there are no redox reactions on the G-P/Cd electrode in the potential range of $-0.3 \mathrm{~V}$ to $0.3 \mathrm{~V}$. Therefore, the oxidation peaks of $\mathrm{Cu} / \mathrm{Cd}$ electrode at ca. $0.05 \mathrm{~V}$ and $0.10 \mathrm{~V}$ should correspond the reaction process that $\mathrm{Cu}$ is oxidized to $\mathrm{Cu}^{1+}$ and the reaction process that $\mathrm{Cu}^{1+}$ continues to be oxidized to $\mathrm{Cu}^{2+}$,
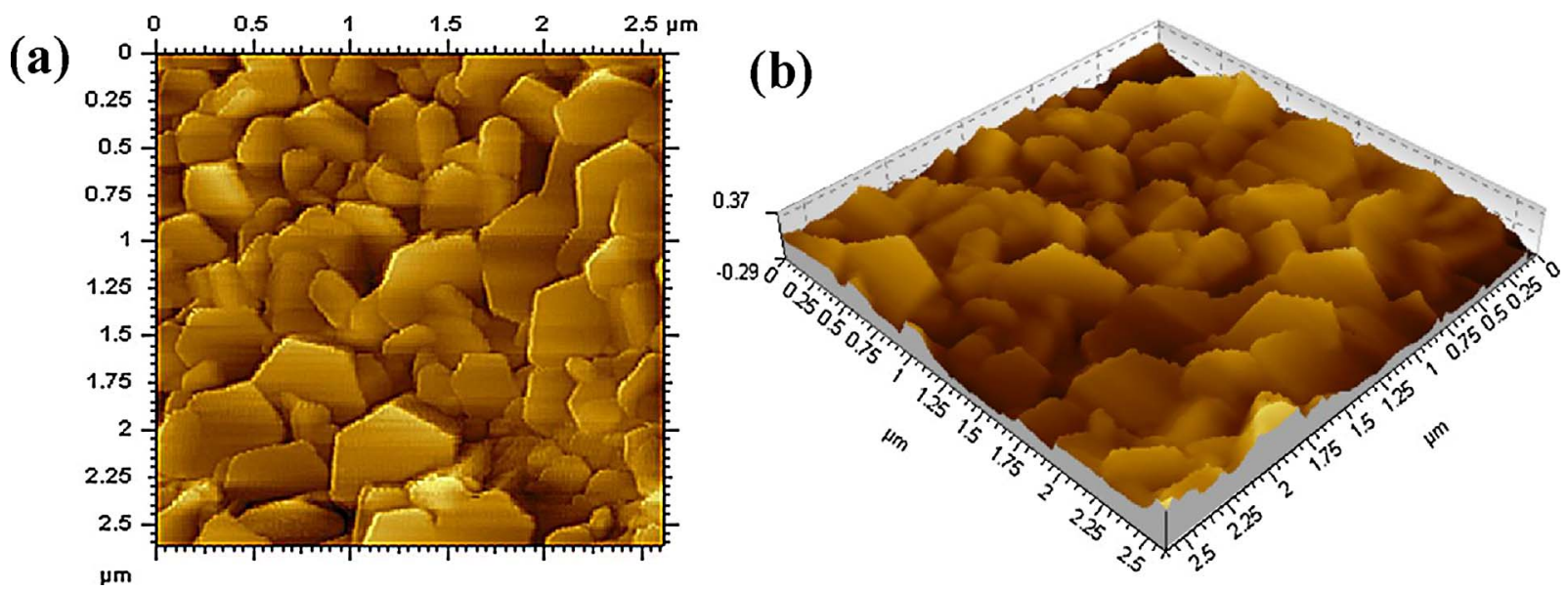

Fig. 2. AFM images of the $\mathrm{Cu} / \mathrm{Cd}$ composite with $300 \mathrm{~nm}$ thick $\mathrm{Cd}$ film on the Cu plate substrate for (a) $2 \mathrm{D}$ figure; (b) $3 \mathrm{D}$ figure. 

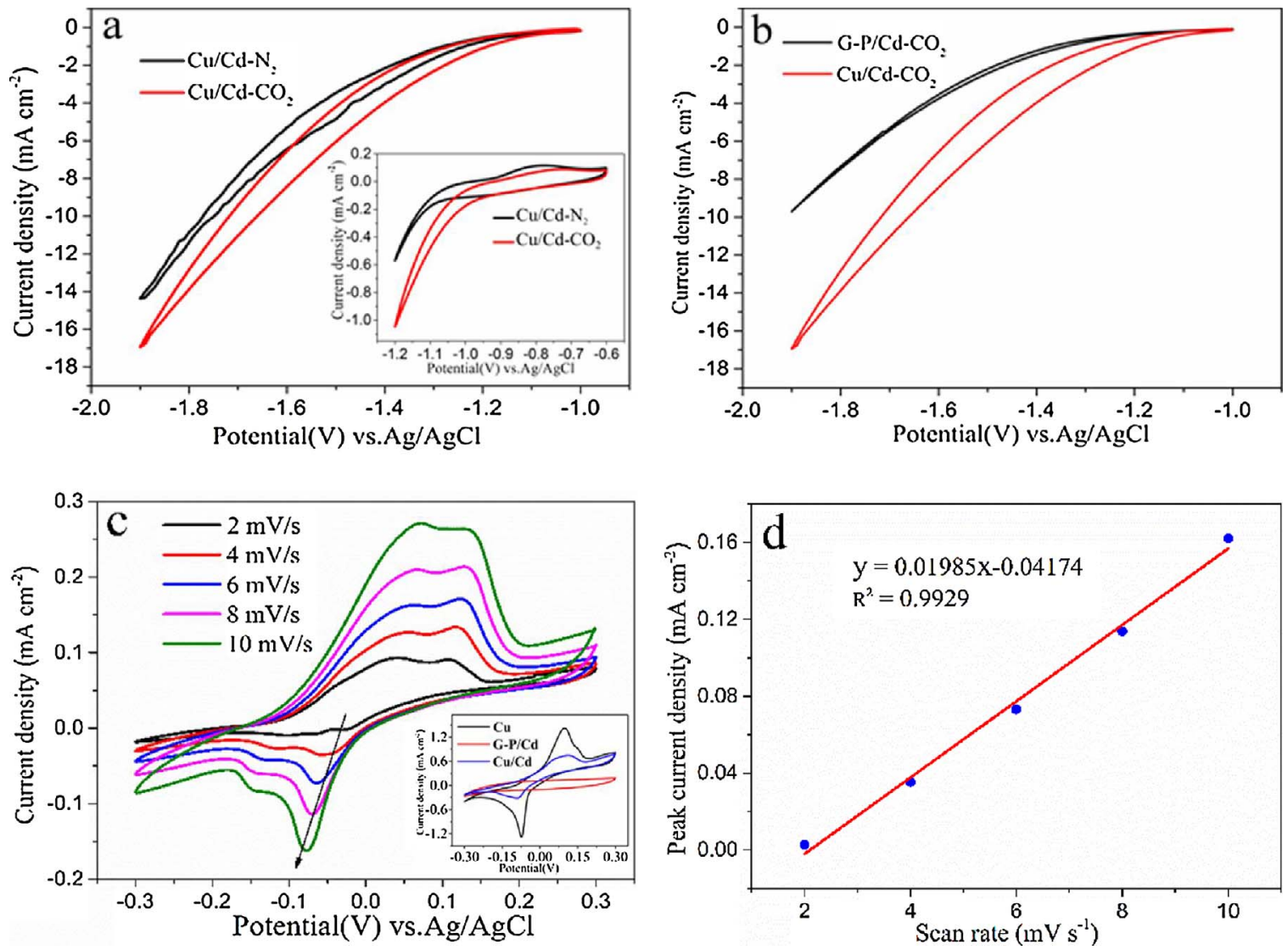

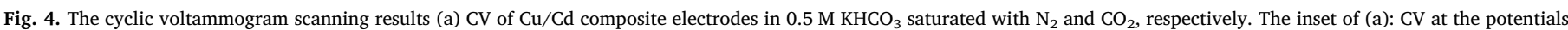

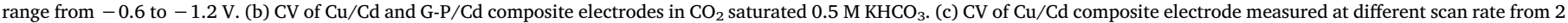
to $10 \mathrm{mV} \mathrm{s}^{-1}$. The inset of (c): $\mathrm{CV}$ of $\mathrm{Cu}, \mathrm{G}-\mathrm{P} / \mathrm{Cd}$ and $\mathrm{Cu} / \mathrm{Cd}$ electrodes at $50 \mathrm{mVs}^{-1}$. (d) Variations of peak current densities with the sweep rates.

respectively; The reduction peaks at ca. $-0.07 \mathrm{~V}$ and $-0.15 \mathrm{~V}$ are assigned to the process that $\mathrm{Cu}^{2+}$ is reduced to $\mathrm{Cu}^{1+}$ and the process that $\mathrm{Cu}^{1+}$ continues to be reduced to $\mathrm{Cu}$, respectively. Fig. $4 \mathrm{~d}$ depicts the variations of peak current densities with the sweep rates corresponding to Fig. 4c. The sweep rates are linearly dependent with the current densities, confirming the electrochemical process is adsorption-limited [43].

Shown in Fig. 5 is the chronoamperogram of the $\mathrm{Cu} / \mathrm{Cd}$ composite electrode in $0.5 \mathrm{M} \mathrm{KHCO}_{3}$ electrolyte solution purged with $\mathrm{CO}_{2}$ at different electrolysis potentials. The results indicate that the current densities increase gradually from 2.2 to $18.1 \mathrm{~mA} \mathrm{~cm}^{-2}$ with the applied potentials increasing from -1.4 to $-1.9 \mathrm{~V}$. It also can be seen that the

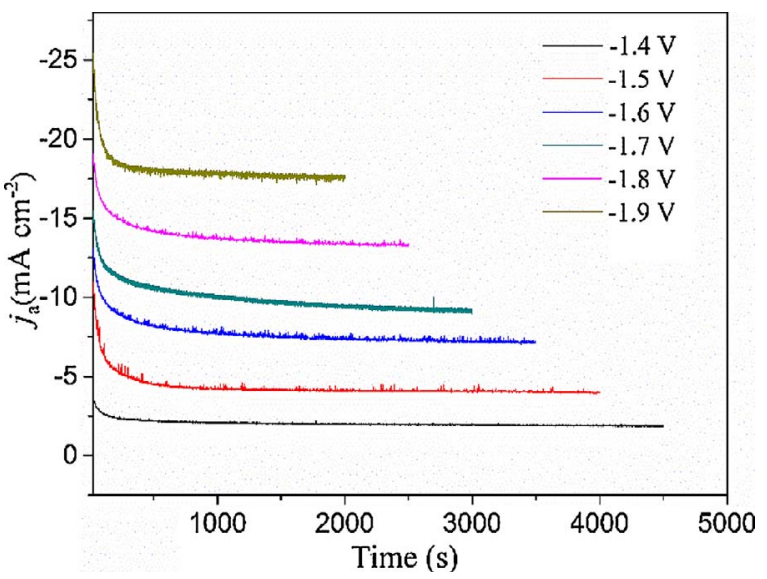

Fig. 5. Chronoamperogram of the $\mathrm{Cu} / \mathrm{Cd}$ composite electrode in $0.5 \mathrm{M} \mathrm{KHCO}_{3}$ electrolyte solution purged with $\mathrm{CO}_{2}$. current density fluctuates at more negative potentials, which is probably caused by the enhancement of $\mathrm{H}_{2}$ evolution reaction at more negative potentials [9]. The violent $\mathrm{H}_{2}$ evolution reaction resulted in a large amount of bubbles produced on the electrode surface during the electrochemical reduction of $\mathrm{CO}_{2}$ at more negative potentials, which interfered with the equilibrium state of the electrode surface. This is consistent with the experimental phenomena that we observed during the electrolysis process.

Fig. 6 depicts the dependence of Faraday efficiency of formate production on the electrolysis potentials on the $\mathrm{Cu} / \mathrm{Cd}$ composite electrode with $100 \mathrm{~nm}$ thick $\mathrm{Cd}$ film during the $\mathrm{CO}_{2}$ reduction. The result shows that the Faradaic efficiency of formate production increases from -1.4 to $-1.8 \mathrm{~V}$ and then decreases for $-1.9 \mathrm{~V}$. The

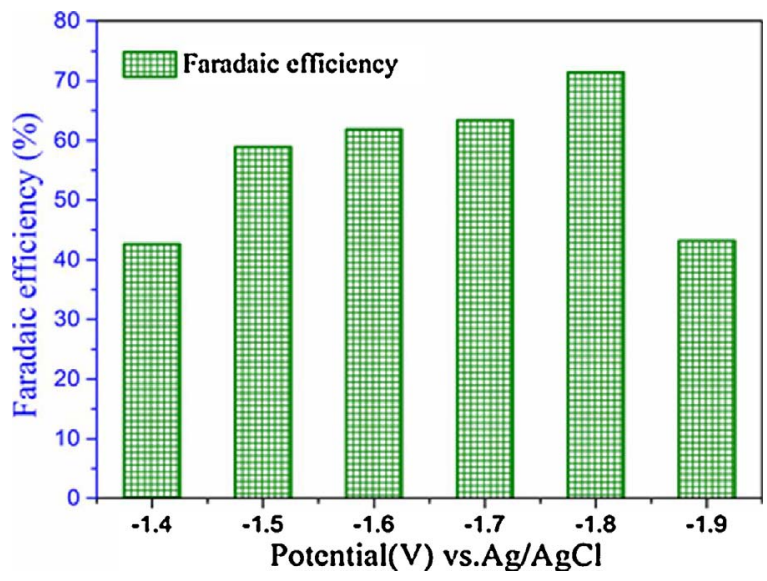

Fig. 6. The dependence of Faraday efficiency on the electrolysis potentials. 


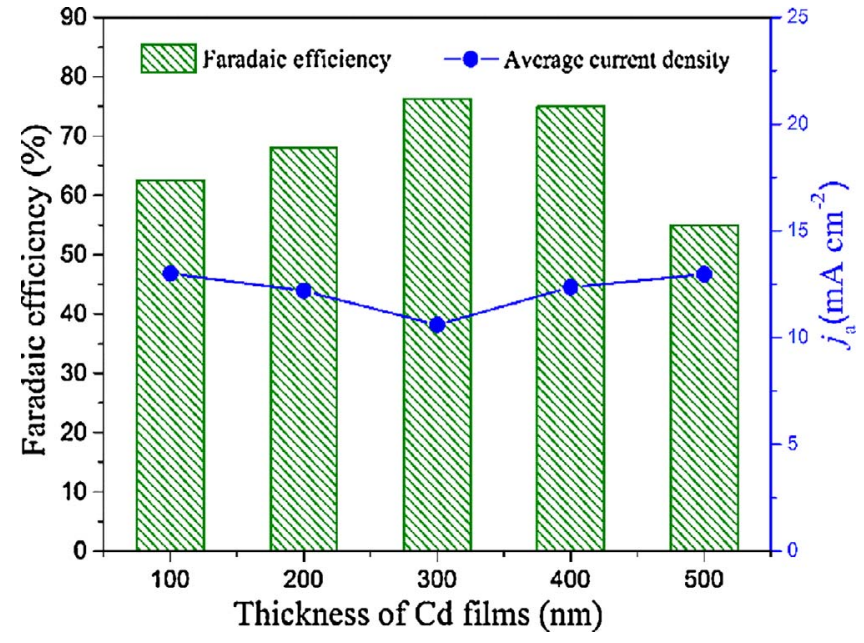

Fig. 7. Variations of the average current density and Faradaic efficiency of formate production with the thickness of $\mathrm{Cd}$ films deposited on $\mathrm{Cu}$ plate substrates.

maximum value $(71.4 \%)$ is obtained at $-1.8 \mathrm{~V}$. The Faradaic efficiency decreases as the electrolysis potential increases further, which can be explained by electrolysis of water results in electric power consumption at more negative potentials. The above results indicate that the appropriate potential toward electrochemical reduction of $\mathrm{CO}_{2}$ on $\mathrm{Cu} / \mathrm{Cd}$ composite electrode could be $-1.8 \mathrm{~V}$ versus the $\mathrm{Ag} / \mathrm{AgCl}$ reference electrode.

The effects of the thickness of Cd film on the electrocatalytic activity of the $\mathrm{Cu} / \mathrm{Cd}$ composite electrode were investigated. It has been known from Fig. 6 that the optimal applied potential is around $1.8 \mathrm{~V}$. Thus, the experiment of Cd film thickness effect was carried out with potential of $-1.8 \mathrm{~V}$. As shown in Fig. 7, a slight change of current density was observed with the thickness of Cd film increasing from 100 to $500 \mathrm{~nm}$. When the thickness of the Cd film was $300 \mathrm{~nm}$, the maximum Faradaic efficiency (76.2\%) for producing formate was achieved, which could be attribute to the appropriate size and accumulation of the Cd flakes at $300 \mathrm{~nm}$. It has been known that the potential for $\mathrm{H}_{2}$ evolution reaction on $\mathrm{Cu}$ is lower than that on $\mathrm{Cd}$ [25]. According to the SEM images, the size of the Cd flakes increase with the thickness of the films decrease, which resulting in the larger pore size between the Cd flakes. The surface of $\mathrm{Cu}$ plate substrate is more easily exposed to the electrolyte and start the $\mathrm{H}_{2}$ evolution reaction, resulting in a lower Faradaic efficiency; In contrast, with the decrease in the size of Cd flakes, the films are denser. Thus, $\mathrm{CO}_{2}$ is difficult to diffuse to the surface of $\mathrm{Cu}$ plate substrate, the electrocatalytic activity of $\mathrm{Cu}$ plate is weakened during the process of $\mathrm{CO}_{2}$ reduction. Therefore, the optimal thickness of the $\mathrm{Cd}$ film deposited the $\mathrm{Cu}$ plate substrate is around $300 \mathrm{~nm}$ due to the proper surface roughness and accessibility of $\mathrm{Cu}$ substrate.

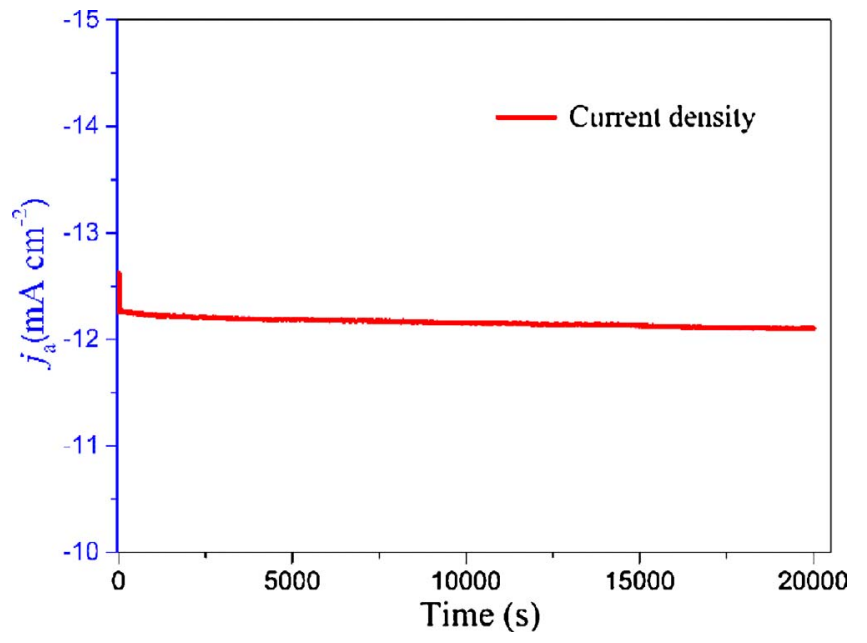

Fig. 9. Chronoamperograms of a $\mathrm{Cu} / \mathrm{Cd}$ composite electrode in $0.5 \mathrm{M}$ aqueous $\mathrm{KHCO}_{3}$ purged with $\mathrm{CO}_{2}$ at the $-1.8 \mathrm{~V}$.

Further electrolysis experiments were carried out on the pure $\mathrm{Cu}$ electrode and the Fig. 8 a shows the product distribution on the $\mathrm{Cu}, \mathrm{G}-\mathrm{P}$ / $\mathrm{Cd}$ and $\mathrm{Cu} / \mathrm{Cd}$ electrodes at the electrolysis potential of $-1.8 \mathrm{~V}$. Comparing $\mathrm{Cu} / \mathrm{Cd}$ to $\mathrm{Cu}$ electrodes, it can be seen that the $\mathrm{Cd}$ film which is deposited on $\mathrm{Cu}$ substrate inhibits the production of $\mathrm{CH}_{4}$ and $\mathrm{H}_{2}$ on the $\mathrm{Cu}$ electrode and the Faradaic efficiency of formate production on $\mathrm{Cu}$ / $\mathrm{Cd}$ composite electrode was significantly improved; Comparing $\mathrm{Cu} / \mathrm{Cd}$ to $\mathrm{G}-\mathrm{P} / \mathrm{Cd}$ electrodes, the results reveal that the $\mathrm{Cu}$ substrate promotes the efficiency of $\mathrm{CO}$ and formate production on the Cd film. Consequently, $\mathrm{Cu}$ substrate and $\mathrm{Cd}$ film play a synergistic role in promoting the production of formate in the composite electrode. The comparison of the $\mathrm{Cu}, \mathrm{G}-\mathrm{P} / \mathrm{Cd}$ and $\mathrm{Cu} / \mathrm{Cd}$ electrodes on average current density, Faraday efficiency and production rate of formate are shown in Fig. 8b. For the $\mathrm{Cu}$ plate, G-P/Cd and $\mathrm{Cu} / \mathrm{Cd}$ electrodes, the average current densities are 17.3, 6.6 and $10.6 \mathrm{~mA} \mathrm{~cm}^{-2}$, respectively; the Faradaic efficiencies are $36.1 \%, 62.0 \%$ and $76.2 \%$, respectively; the production rates are $5.1,3.4$ and $6.7 \mathrm{~g} \mathrm{~L}^{-1} \mathrm{day}^{-1}$, respectively. The $\mathrm{Cu}$ plate electrode exhibits the highest current density, whereas the Faradaic efficiency is great lower than the other two electrodes. As previously reported that the $\mathrm{Cu}$ electrodes showed low Faradaic efficiency of formate production toward $\mathrm{CO}_{2}$ reduction [28,37]. The Faradic efficiency and production rate on $\mathrm{Cu} / \mathrm{Cd}$ composite electrode is higher than that on the $\mathrm{Cu}$ plate and G-P/Cd electrodes. Together, these results indicate that depositing a layer of $\mathrm{Cd}$ film on the $\mathrm{Cu}$ plate substrate can enhance electrocatalytic activity of $\mathrm{Cu}$ plate electrode for producing formate.

Shown in Fig. 9 is the chronoamperogram of the $\mathrm{Cu} / \mathrm{Cd}$ composite electrode with $300 \mathrm{~nm}$ thick $\mathrm{Cd}$ film in $0.5 \mathrm{M}$ aqueous $\mathrm{KHCO}_{3}$ purged with $\mathrm{CO}_{2}$ at the $-1.8 \mathrm{~V}$. The current density only decreases from
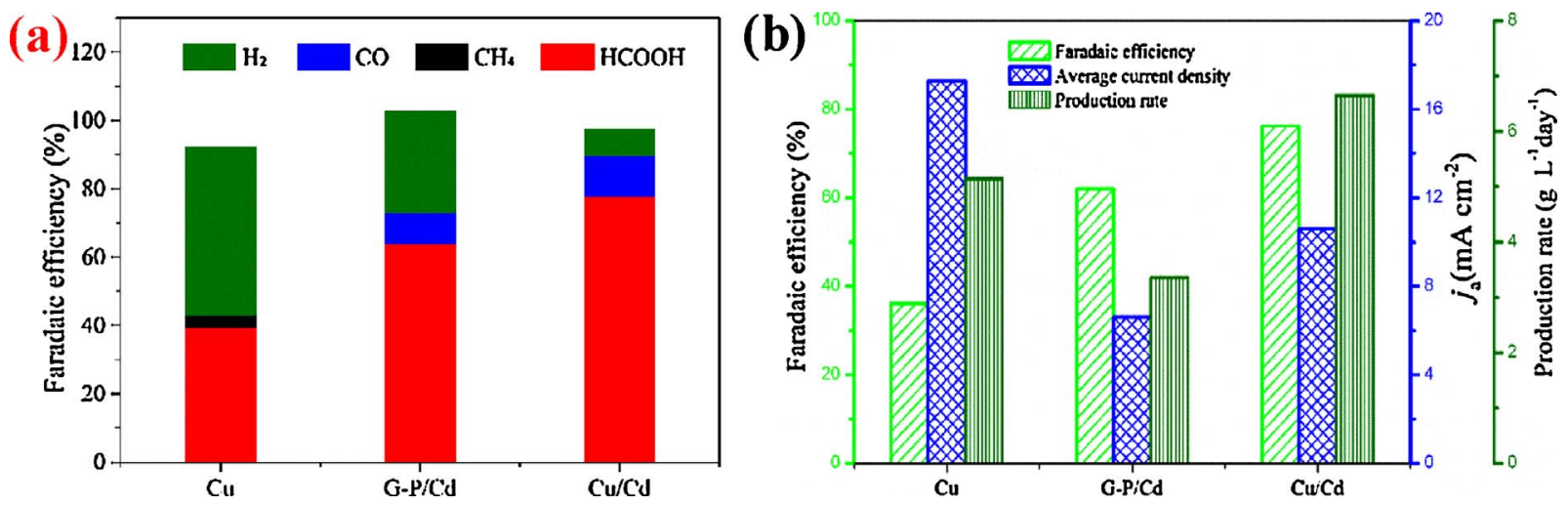

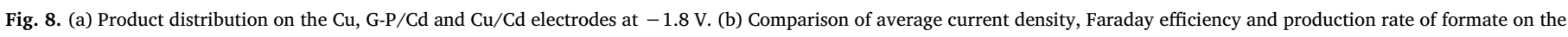
$\mathrm{Cu}, \mathrm{G}-\mathrm{P} / \mathrm{Cd}$ and $\mathrm{Cu} / \mathrm{Cd}$ electrodes at $-1.8 \mathrm{~V}$. 
$12.3 \mathrm{~mA} \mathrm{~cm}^{-2}$ to $12.1 \mathrm{~mA} \mathrm{~cm}^{-2}$ after continuous electrolysis for $20,000 \mathrm{~s}$. The result indicates that the attenuation of current density on $\mathrm{Cu} / \mathrm{Cd}$ composite electrode is negligible during the long time process of $\mathrm{CO}_{2}$ reduction. This suggests the $\mathrm{Cu} / \mathrm{Cd}$ composite electrode which is prepared by vacuum evaporation coating $\mathrm{Cd}$ film on the $\mathrm{Cu}$ plate substrate has excellent stability.

\section{Conclusions}

The $\mathrm{Cu} / \mathrm{Cd}$ composite electrode was prepared by vacuum evaporation coating $\mathrm{Cd}$ film on the Cu plate substrate. The SEM, AFM and XRD results reveal that the $\mathrm{Cd}$ film was deposited on the $\mathrm{Cu}$ plate substrate successfully with novel flaky shape and the crystal forms of $\mathrm{Cu}$ and $\mathrm{Cd}$ has not been destroyed in the process of preparing the $\mathrm{Cu} / \mathrm{Cd}$ composite electrode. The performance of $\mathrm{CO}_{2}$ reduction on the $\mathrm{Cu} / \mathrm{Cd}$ composite electrode has been studied by controlled potential electrolysis and cyclic voltammetry in $0.5 \mathrm{M} \mathrm{KHCO}_{3}$. The results indicate that the Faradaic efficiency of formate production is related to the applied potential and the thickness of $\mathrm{Cd}$ film. The appropriate potential for producing formate efficiently should be around $-1.8 \mathrm{~V}$ and the optimal thickness of the $\mathrm{Cd}$ film is around $300 \mathrm{~nm}$ in this experiment. The maximum Faradaic efficiency of $76.2 \%$ for formate production was achieved with high stability and current densities of $10.6 \mathrm{~mA} \mathrm{~cm}^{-2}$ on the $\mathrm{Cu} / \mathrm{Cd}$ composite electrode. Furthermore, the electrocatalytic activity of the $\mathrm{Cu} / \mathrm{Cd}$ composite electrode for $\mathrm{CO}_{2}$ reduction have been enhanced compared with the pure $\mathrm{Cu}$ plate electrode and G-P/Cd composite electrode. Together, it can be concluded that the preparation method used in this experiment is a simple and cost effective way of manufacturing composite electrodes and the $\mathrm{Cu} / \mathrm{Cd}$ composite electrode exhibits excellent performance on $\mathrm{CO}_{2}$ reduction.

\section{Acknowledgements}

This work was supported by the CAS Hundred Talent Program and the National Natural Science Foundation of China (Grant No. 21676288).

\section{References}

[1] S. Zhang, P. Kang, S. Ubnoske, M.K. Brennaman, N. Song, R.L. House, J.T. Glass, T.J. Meyer, Polyethylenimine-enhanced electrocatalytic reduction of $\mathrm{CO}_{2}$ to formate at nitrogen-doped carbon nanomaterials, J. Am. Chem. Soc. 136 (2014) $7845-7848$.

[2] T. Huan, E.S. Andreiadis, J. Heidkamp, P. Simon, E. Derat, S. Cobo, G. Royal, A. Bergmann, P. Strasser, H. Dau, From molecular copper complexes to composite electrocatalytic materials for selective reduction of $\mathrm{CO}_{2}$ to formic acid, J. Mater. Chem. A 3 (2015) 3901-3907.

[3] S. Rasul, D.H. Anjum, A. Jedidi, Y. Minenkov, L. Cavallo, K. Takanabe, A highly selective copper-indium bimetallic electrocatalyst for the electrochemical reduction of aqueous CO2 to CO, Angew. Chem. Int. Ed. 54 (2015) 2146-2150.

[4] D. Gao, H. Zhou, J. Wang, S. Miao, F. Yang, G. Wang, J. Wang, X. Bao, Size-dependent electrocatalytic reduction of $\mathrm{CO}_{2}$ over Pd nanoparticles, J. Am. Chem. Soc. 137 (2015) 4288-4291.

[5] A.A. Peterson, How copper catalyzes the electroreduction of carbon dioxide into hydrocarbon fuels, Energy Environ. Sci. 3 (2010) 1311-1315.

[6] H. Yang, J.J. Kaczur, S.D. Sajjad, R.I. Masel, Electrochemical conversion of $\mathrm{CO}_{2}$ to formic acid utilizing Sustainion ${ }^{\mathrm{TM}}$ membranes, J. CO 2 Util. 20 (2017) 208-217.

[7] B. Innocent, D. Liaigre, D. Pasquier, F. Ropital, J.-M. Léger, K. Kokoh, Electro-reduction of carbon dioxide to formate on lead electrode in aqueous medium, J. Appl. Electrochem. 39 (2009) 227.

[8] H. Uslu, C. Bayat, S. Gökmen, Y. Yorulmaz, Reactive extraction of formic acid by Amberlite LA-2 extractant, J. Chem. Eng. Data 54 (2008) 48-53.

[9] Y. Wang, J. Zhou, W. Lv, H. Fang, W. Wang, Electrochemical reduction of $\mathrm{CO}_{2}$ to formate catalyzed by electroplated tin coating on copper foam, Appl. Surf. Sci. 362 (2016) 394-398.

[10] N. Danilovic, R. Subbaraman, K.-C. Chang, S.H. Chang, Y.J. Kang, J. Snyder, A.P. Paulikas, D. Strmcnik, Y.-T. Kim, D. Myers, Activity-stability trends for the oxygen evolution reaction on monometallic oxides in acidic environments, J. Phys. Chem. Lett. 5 (2014) 2474-2478.

[11] J. Yang, C. Tian, L. Wang, H. Fu, An effective strategy for small-sized and highlydispersed palladium nanoparticles supported on graphene with excellent performance for formic acid oxidation, J. Mater. Chem. 21 (2011) 3384-3390.

[12] M. Todoroki, K. Hara, A. Kudo, T. Sakata, Electrochemical reduction of high pressure $\mathrm{CO}_{2}$ at $\mathrm{Pb}, \mathrm{Hg}$ and In electrodes in an aqueous $\mathrm{KHCO}_{3}$ solution, J. Electroanal. Chem. 394 (1995) 199-203.
[13] W. Lv, R. Zhang, P. Gao, L. Lei, Studies on the faradaic efficiency for electrochemical reduction of carbon dioxide to formate on tin electrode, J. Power Sources 253 (2014) 276-281.

[14] S. Kaneco, K. Iiba, H. Katsumata, T. Suzuki, K. Ohta, Electrochemical reduction of high pressure carbon dioxide at a $\mathrm{Cu}$ electrode in cold methanol with $\mathrm{CsOH}$ supporting salt, Chem. Eng. J. 128 (2007) 47-50.

[15] K. Ohta, K. Suda, S. Kaneco, T. Mizuno, Electrochemical reduction of carbon dioxide at Cu electrode under ultrasonic irradiation, J. Electrochem. Soc. 147 (2000) 233-237.

[16] J. Christophe, T. Doneux, C. Buess-Herman, Electroreduction of carbon dioxide on copper-based electrodes: activity of copper single crystals and copper-gold alloys, Electrocatalysis 3 (2012) 139-146.

[17] S. Gao, Y. Lin, X. Jiao, Y. Sun, Q. Luo, W. Zhang, D. Li, J. Yang, Y. Xie, Partially oxidized atomic cobalt layers for carbon dioxide electroreduction to liquid fuel, Nature 529 (2016) 68-71.

[18] Z.M. Detweiler, J.L. White, S.L. Bernasek, A.B. Bocarsly, Anodized indium metal electrodes for enhanced carbon dioxide reduction in aqueous electrolyte, Langmui 30 (2014) 7593-7600.

[19] G.S. Prakash, F.A. Viva, G.A. Olah, Electrochemical reduction of $\mathrm{CO}_{2}$ over $\mathrm{Sn}$ Nafion coated electrode for a fuel-cell-like device, J. Power Sources 223 (2013) 68-73.

[20] M. Alvarez-Guerra, S. Quintanilla, A. Irabien, Conversion of carbon dioxide into formate using a continuous electrochemical reduction process in a lead cathode, Chem. Eng. J. 207 (2012) 278-284.

[21] A. Del Castillo, M. Alvarez-Guerra, J. Solla-Gullón, A. Sáez, V. Montiel, A. Irabien, Electrocatalytic reduction of $\mathrm{CO}_{2}$ to formate using particulate $\mathrm{Sn}$ electrodes: effect of metal loading and particle size, Appl. Energy 157 (2015) 165-173.

[22] H.-Z. Zhao, Y. Zhang, Y.-Y. Chang, Z.-S. Li, Conversion of a substrate carbon source to formic acid for carbon dioxide emission reduction utilizing series-stacked microbial fuel cells, J. Power Sources 217 (2012) 59-64.

[23] Y. Hori, K. Kikuchi, S. Suzuki, Production of $\mathrm{CO}$ and $\mathrm{CH}_{4}$ in electrochemical reduction of $\mathrm{CO}_{2}$ at metal electrodes in aqueous hydrogencarbonate solution, Chem. Lett. 14 (1985) 1695-1698.

[24] S. Ikeda, T. Takagi, K. Ito, Selective formation of formic acid oxalic acid, and carbon monoxide by electrochemical reduction of carbon dioxide, B. Chem. Soc. Jpn. 60 (1987) 2517-2522.

[25] M. Watanabe, M. Shibata, A. Kato, M. Azuma, T. Sakata, Design of alloy electrocatalysts for $\mathrm{CO}_{2}$ reduction III. The selective and reversible reduction of on $\mathrm{Cu}$ alloy electrodes, J. Electrochem. Soc. 138 (1991) 3382-3389.

[26] E. Andrews, S. Katla, C. Kumar, M. Patterson, P. Sprunger, J. Flake, Electrocatalytic reduction of $\mathrm{CO}_{2}$ at Au nanoparticle electrodes: effects of interfacial chemistry on reduction behavior, J. Electrochem. Soc. 162 (2015) F1373-F1378.

[27] Q. Lu, J. Rosen, Y. Zhou, G.S. Hutchings, Y.C. Kimmel, J.G. Chen, F. Jiao, A selective and efficient electrocatalyst for carbon dioxide reduction, Nat. Commun. 5 (2014) 3242.

[28] S. Sen, D. Liu, G.T.R. Palmore, Electrochemical reduction of CO2 at copper nanofoams, ACS Catal. 4 (2014) 3091-3095.

[29] Y. Hori, K. Kikuchi, A. Murata, S. Suzuki, Production of methane and ethylene in electrochemical reduction of carbon dioxide at copper electrode in aqueous hydrogencarbonate solution, Chem. Lett. 15 (1986) 897-898.

[30] C.W. Li, M.W. Kanan, $\mathrm{CO}_{2}$ reduction at low overpotential on $\mathrm{Cu}$ electrodes resulting from the reduction of thick Cu2O films, J. Am. Chem. Soc. 134 (2012) 7231-7234.

[31] W. Zhu, R. Michalsky, O.N. Metin, H. Lv, S. Guo, C.J. Wright, X. Sun, A.A. Peterson, S. Sun, Monodisperse Au nanoparticles for selective electrocatalytic reduction of CO2 to CO, J. Am. Chem. Soc. 135 (2013) 16833-16836.

[32] P. Huang, S. Ci, G. Wang, J. Jia, J. Xu, Z. Wen, High-activity Cu nanowires electrocatalysts for $\mathrm{CO} 2$ reduction, J. $\mathrm{CO}_{2}$ Util. 20 (2017) 27-33.

[33] A. Katoh, H. Uchida, M. Shibata, M. Watanabe, Design of electrocatalyst for $\mathrm{CO}_{2}$ reduction V. effect of the microcrystalline structures of $\mathrm{Cu}-\mathrm{Sn}$ and $\mathrm{Cu}-\mathrm{Zn}$ alloys on the electrocatalysis of reduction, J. Electrochem. Soc. 141 (1994) 2054-2058.

[34] W. Lv, J. Zhou, J. Bei, R. Zhang, F. Kong, W. Wang, Electrodeposition of tin based film on copper plate for electrocatalytic reduction of carbon dioxide to formate, Int J. Electrochem. Sci. 11 (2016) 6183-6191.

[35] A. Loiudice, P. Lobaccaro, E.A. Kamali, T. Thao, B.H. Huang, J.W. Ager, R. Buonsanti, Tailoring copper nanocrystals towards C2 products in electrochemical $\mathrm{CO}_{2}$ reduction, Angew. Chem. Int. Ed. 55 (2016) 5789-5792.

[36] B. Jermann, J. Augustynski, Long-term activation of the copper cathode in the course of $\mathrm{CO}_{2}$ reduction, Electrochim. Acta 39 (1994) 1891-1896.

[37] J. Qiao, P. Jiang, J. Liu, J. Zhang, Formation of Cu nanostructured electrode surfaces by an annealing-electroreduction procedure to achieve high-efficiency CO2 electroreduction, Electrochem. Commun. 38 (2014) 8-11.

[38] W. Tang, A.A. Peterson, A.S. Varela, Z.P. Jovanov, L. Bech, W.J. Durand, S. Dahl, J.K. Nørskov, I. Chorkendorff, The importance of surface morphology in controlling the selectivity of polycrystalline copper for $\mathrm{CO}_{2}$ electroreduction, Phys. Chem. Chem. Phys. 14 (2012) 76-81.

[39] Y. Hori, A. Murata, S.-y. Ito, Enhanced evolution of CO and suppressed formation of hydrocarbons in electroreduction of $\mathrm{CO} 2$ at a copper electrode modified with cadmium, Chem. Lett. 19 (1990) 1231-1234.

[40] Y. Hori, I. Takahashi, O. Koga, N. Hoshi, Electrochemical reduction of carbon dioxide at various series of copper single crystal electrodes, J. Mol. Catal. A: Chem. 199 (2003) 39-47.

[41] K.J.P. Schouten, E. Pérez Gallent, M.T. Koper, Structure sensitivity of the electrochemical reduction of carbon monoxide on copper single crystals, ACS Catal. 3 (2013) 1292-1295.

[42] R. Zhang, W. Lv, L. Lei, Role of the oxide layer on Sn electrode in electrochemical reduction of $\mathrm{CO}_{2}$ to formate, Appl. Surf. Sci. 356 (2015) 24-29.

[43] L. Siinor, J. Poom, C. Siimenson, K. Lust, E. Lust, Electrochemical characteristics pyrolytic graphite mixture of 1-ethyl-3-methylimidazolium tetrafluoroborate and 1 ethyl-3-methylimidazolium iodide interface, J. Electroanal. Chem. 719 (2014) 133-137. 